\title{
Antimicrobial Activities of Sponge-Derived Microorganisms from Coastal Waters of Central Vietnam
}

\author{
Pham Thi Mien ${ }^{1, *}$, Dao Viet Ha ${ }^{1}$, Hoang Xuan Ben ${ }^{1}$, Bin Chen ${ }^{2}$, Lan Liu ${ }^{2} \mathbb{C}$ \\ and Phan Minh-Thu 1,3,*(D) \\ 1 Institute of Oceanography, Vietnam Academy of Science and Technology (VAST), \\ Nha Trang 650000, Vietnam; daovietha69@gmail.com (D.V.H.); hxuanben@yahoo.com (H.X.B.) \\ 2 The School of Marine Science, Sun Yat-Sen University, Guangzhou 510006, China; \\ chenbin25@mail.sysu.edu.cn (B.C.); cesllan@mail.sysu.edu.cn (L.L.) \\ 3 School of Marine Science and Technology, Graduate University of Science and Technology, \\ VAST, Ha Noi 100000, Vietnam \\ * Correspondence: mien.pham@gmail.com (P.T.M.); phanminhthu@vnio.org.vn (P.M.-T.)
}

Received: 26 June 2020; Accepted: 5 August 2020; Published: 8 August 2020

\begin{abstract}
Bacteria associated with invertebrates are considered as good sources for biologically active compounds. Sponge-derived bacteria were screened for antimicrobial activities, the presence of the cluster genes of polyketide synthases (PKSs) and non-ribosomal peptide synthetases (NRPSs), and through a colony picking method. Crude extracts of broth cultures were tested for microbial inhibition. Eleven out of 25 isolated strains showed inhibition of at least one of eight tested indicator microorganisms. Antimicrobial activities were observed in the strains coded HM5, HM6, and HM9 with the presence of NRPS and PKSII genes, whereas the isolate HM21 held both NRPS and PKSII and inhibited only the growth of Bacillus subtilis by the well diffusion method and only inhibited Serratia marcescens by the colony picking method. Two isolates, HM5 and HM6, belonged to the species of Bacillus. Interestingly, the isolate HM9 was nearest to Streptomyces mexicanus ${ }^{\mathrm{T}}$ NBRC100915 (GenBank accession number AB249966) with 94\% sequence similarity. This potent strain HM9 could possibly be considered as a new species and a good source for bioactive compound discovery. Some isolates showed NRPS/PKS genes but did not exhibit antimicrobial activity. Thus, we suggested that both molecular and traditional methods should be conducted for the screening of antimicrobial producers.
\end{abstract}

Keywords: sponge-associated bacteria; antimicrobial activities; Streptomyces; Bacillus

\section{Introduction}

Reversing fossil evidence from about 635 to 750 million years ago, Porifera is one of the most ancient living organisms [1] and is considered as an excellent source of drug materials. It is evident that $99 \%$ of the total of 15,000 species of marine mammals are capable of serving as biologically active substance producers [2]. Polyketide synthases (PKSs) and non-ribosomal peptide synthetases (NRPSs) are a huge source of bioactive compounds, which have been found from Archaea and Eukarya, and are most commonly found in bacteria; they are abundant in the phyla of Actinobacteria, Firmicutes, Proteobacteria, and Cyanobacteria and in the fungal phylum of Ascomycota. Marine microorganisms have been reported as a source of peptides, such as those harvested from soil inhabiting Actinomycete and Bacillus [3]. Those gene clusters are coded for multifunctional enzymes involved in the synthesis of natural bioactive compounds, many of which were proved to become drugs for humans. The Bacillus genus is a good source of well-known antibiotics such as lipopeptides (LPs) and polyketides, which were 
originally generated by NRPS and PKS, respectively [4,5]. Additionally, Bacillus and Streptomyces are well known as producers of bioactive compounds with more than 10,000 natural compounds, which were isolated from these genera only [6]. Antibiotic bleomycin is a glycopeptide produced by Streptomyces verticillus, which is a compound that showed anticancer activities [7]. The well-known Streptomyces derived from the sponge Haliclona sp. produced known antibiotics and some anti-cancer agents [8]. Among the 46 Gram-positive isolates from five sponge species from the deep-sea of Antarctica, 24 isolates belonged to Actinobacteria, including 6 genera, namely Streptomyces, Nocardiopsis, Pseudonocardia, Dietzia, Brachybacterium, and Brevibacterium. The last 22 strains were Firmicutes. Seventy percent of the total 46 strains had type I of the PKS gene (PKSI), whereas $85 \%$ possessed type II of the PKS gene (PKSII), and $88 \%$ of crude extracts from those holding PKS strains showed inhibition of at least one of four indicator test strains [9].

Another aspect has been controversial, namely when several dozen kilograms of Halichondria, Ecteinascidia, or Bugula were harvested just to obtain a gram of purified substance of halichondrin, ecteinascidin, or bryostatin, respectively, as well as unsolvable problems when carrying out the mariculture of those marine animals to collect raw materials for further studies [10,11]. Moreover, there is growing evidence that the "main producers" of natural substances are associated with microorganisms rather than their hosts [10-12]. Indeed, marine microorganisms are being studied and are promising candidates for drug discovery in the near future [13,14]. Furthermore, challenges to the marine ecosystem were revealed when large amounts of sponge samples were collected for bioactive compound screening and pure substance isolation [15-17]. It becomes a threat to the single species when the understanding of sponge diversity and its distribution in the Vietnamese sea is limited.

Most recently, Ton et al. [18] reported the diversity of archaea- and bacteria-associated sponges using 16s rRNA gene for Illumina MiSeq sequencing. In that study, a total of 27 sponge specimens from the central coastal zone of Vietnam were investigated. However, investigation of sponge-associated microorganisms for bioactive compounds is still unexplored.

The huge marine bacterial strains were screened for bioactive compounds by culture-dependent methods beginning with isolation, then preservation, and then antimicrobial testing. We proceeded here firstly with the screening of the presence of PKS/NRPS strains, secondly with antimicrobial testing, and then with preservation only potential strains, which possess those cluster genes and antimicrobial activities. Two negative test strains used in this study were human pathogenic bacteria Escherichia coli strain 0157 and Serratia marcescens strain PDL100, which causes fatal disease for the elkhorn coral, Acropora palmata, in the Florida Keys. The reference strains of Bacillus subtilis ATCC6633, Staphylococcus aureus ATCC12228, Salmonella typhimurium ATCC6994, E. coli 0157, and Candida albicans ATCC10231 were used as test strains for antimicrobial activities. Additionally, the other two pathogenic bacteria, Vibrio campbellii and Vibrio parahaemolyticus, isolated from the bleaching coral Acropora sp. at the sponge sampling site, were used as test strains in this present study.

This approach may help to save time for screening and also save the antimicrobial producing strains that were normally ignored when they did not show any positive results from traditional methods. This present study is the first to screen for antimicrobial producers of microbes associated with the sponge from the Vietnamese sea and provides a foundation for the next studies on natural substances and for seeking development of pre-biotics or probiotics for aquaculture.

\section{Materials and Methods}

\subsection{Sample Collection}

The living sponge (Figure 1) was collected through SCUBA diving at ca. $6 \mathrm{~m}$ in depth in Mot Island (109 $\left.16^{\prime} 23^{\prime \prime} \mathrm{E}, 12^{\circ} 10^{\prime} 55^{\prime \prime} \mathrm{N}\right)$, Nha Trang Bay, in the center of Vietnam. The sponge was identified as Aaptos suberitoides [19]. The voucher specimen was deposited at the Department of Marine Living Resources, Institute of Oceanography, VAST. After collecting, the specimen was preserved in a sterile 
dark polyethylene bag, stored in an ice-box, and transferred to the laboratory as soon as possible for further analysis.

Before collecting the sponge, the water environmental parameters were measured by the water quality profile of AAQ 1183 (ALEC, Japan). The temperature was $28.1-28.3^{\circ} \mathrm{C}$, and the oxygen dissolved concentration was $6.03-6.12 \mathrm{mg} / \mathrm{L}$.

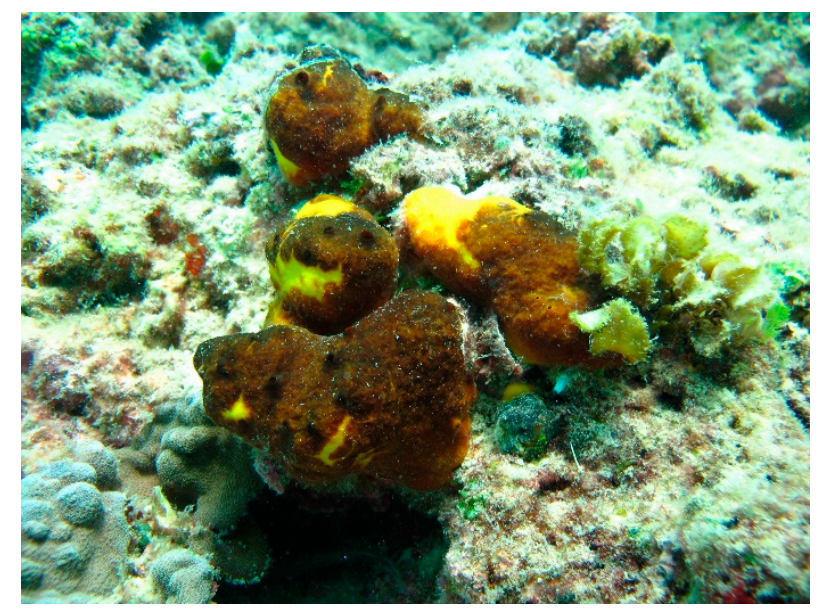

Figure 1. Aaptos suberitoides underwater at Mot Island in Nha Trang Bay (Photo: Thai Minh Quang).

\subsection{Isolation of Sponge-Associated Bacteria-SAB and Test Strain Vibrio sp.}

In the laboratory, the natural seawater collected at the sampling site was filtered using Whatman Glass microfiber filters (GF/F $0.45 \mu \mathrm{m}$ ) to remove suspended sediment and particular organic matter; after that, the seawater was sterilized by a Hirayama HV-II autoclave at $121{ }^{\circ} \mathrm{C}$ and $1 \mathrm{~atm}$ for $20 \mathrm{~min}$. The sterile natural seawater was used to treat sponge and coral specimens and for experimental applications.

In the laboratory, the sponge specimen was washed three times with the sterile natural seawater for $5 \mathrm{~min}$ to remove surface-attached microbes. The sponge specimen was sterile crushed with a pestle and mortar. A total of aerobic microorganisms in $1 \mathrm{~g}$ of fresh sponge was counted as $1.31 \times 10^{5} \mathrm{cfu} / \mathrm{g}$, corresponding to 218 and 175 colonies at dilution concentrations of $10^{-2}$ and $10^{-3}$ with 80 and 103 colonies, respectively; at a dilution of $10^{-4}$, less than 30 colonies were recorded, and most of them were the same in shape and size. Then, it was diluted with the sterile natural seawater to a dilution of $10^{-5}$ to have a homogenized sample. The $100 \mu \mathrm{L}$ of the homogenized sample was spread onto the R2A agar plates; then, the streaking plate method was used to get pure isolates. The isolates were preserved in marine broth plus $50 \%$ glycerol at a room temperature of ca. $30{ }^{\circ} \mathrm{C}$. A total of 25 distinct culture colonies in shapes, colors, and sizes was selected for antimicrobial screening.

A branch of bleaching coral, Acropora sp., at the same sampling site, was sampled for isolation of Vibrio sp. with selected media, namely TCBS (HiMedia-India) and ChromagarTM Vibrio (CHROMagar-France). The strain V1 was confirmed as Vibrio parahaemolyticus when it showed green color on TCBS and mauve color on Chromagar ${ }^{\mathrm{TM}}$ Vibrio and $99 \%$ sequence similarity to the 16s RNA gene. The strain V2 was found in yellow color and a large colony, and it changed the medium's color on TCBS and was colorless on CHROMagar ${ }^{\mathrm{TM}}$. The partial sequence of 16s RNA showed that V2 could be Vibrio campbellii with $98 \%$ sequence identity. This occasional pathogenic bacteria $V$. parahaemolyticus and V. campbellii were used as test strains in this present study and were preserved in $20 \%$ glycerol at $-80{ }^{\circ} \mathrm{C}$.

The 16s RNA gene method to determinate Vibrio sp. is as follows: (1) Universal primer sets of 27F, 1500R were used for amplification of the 16S rRNA gene with the PuReTaq ${ }^{\mathrm{TM}}$ Ready-To-Go тм PCR Beads (Healthcare) with a total volume of $25 \mu \mathrm{L}$, including $5 \mu \mathrm{L}$ DNA templates (50 ng), 10 pmol 27F, 10 pmol 1500R, and DNA-free H2O (Sigma). The PCR reaction conditions included initial 
denaturation $\left(2 \min\right.$ at $\left.94^{\circ} \mathrm{C}\right)$, followed by 30 primer annealing cycles $\left(40 \mathrm{~s}\right.$ at $\left.50^{\circ} \mathrm{C}\right)$, and extended primer extension $\left(90 \mathrm{~s}\right.$ at $\left.72{ }^{\circ} \mathrm{C}\right)$, followed by denaturation $\left(1 \mathrm{~min}\right.$ at $\left.42^{\circ} \mathrm{C}\right)$, and final primer annealing ( $1 \mathrm{~min}$ at $42{ }^{\circ} \mathrm{C}$ ), then extended final extension $\left(5 \mathrm{~min}\right.$ at $\left.72{ }^{\circ} \mathrm{C}\right) .(2)$ The PCR products were sequenced with 342f (5'-TACGGGAGGCAGCAG-3'), 790f (5'-GATACCCTGGTAGTCC-3'), and reverse 543r (5'-ATTACCGCGGCTGCTGG-3'). The sequences were alignment with SeqMan ${ }^{\mathrm{TM}}$ II (DNAStar) and compared with the highest 16s rRNA gene homologs on the gene bank (National Center for Biotechnology Information NCBI) using Nucleotide blast/NCBI (http://blast.ncbi.nlm.nih.gov/Blast. cgi) [20].

\subsection{Screening of Strains for PKS and NRPSs}

DNA was extracted by a single colony picking the pure cultures into $1 \mathrm{~mL} \mathrm{ddH}_{2} \mathrm{O}$, and centrifugation at $8000 \times g$ at $4{ }^{\circ} \mathrm{C}$ for $1 \mathrm{~min}$; cell pellets were used for extracting DNA with a DNA isolation kit (Enzup DNA isolation KIT, Sangon Biotech, China). Extracted DNA was detected by agarose gel electrophoresis ( $1 \%$ agarose) and were used as templates for amplification of PKS and NRPS cluster genes with a set of primers A3F (5'-GCS TAC SYS ATS TAC ACS TCS GG-3') and A7R (5'-SAS GTC VCC SGT SCG GTA S-3') targeting NRPS with 700-800 bp in genes length; K1F (5'-TSA AGT CSA ACA TCG GBC A-3') and M6R (5'-CGC AGG TTS CSG TAC CAG TA-3') targeting PKSI genes with 1200-1400 bp [21]; and PF6 (5'-TSG CST GCT TGG AYG CSA TC- $\left.3^{\prime}\right)$ and PR6 (5'-TGG AAN CCG CCG AAB CCG CT-3') targeting PKSII genes with 600-700 pb [22]. In that sequence, note that $B$ $=\mathrm{C} / \mathrm{T} / \mathrm{G}, \mathrm{I}=$ Inosine, $\mathrm{K}=\mathrm{G} / \mathrm{T}, \mathrm{N}=\mathrm{A} / \mathrm{G} / \mathrm{C} / \mathrm{T}$, and $\mathrm{S}=\mathrm{G} / \mathrm{C}, \mathrm{Y}=\mathrm{C} / \mathrm{T}$.

All the PCR products of PKS and NRPS were visible under ultraviolet fluorescence after Gold View staining with a molecular size marker 2000 bp (DL 2000 DNA Marker, TaKaRa, Japan). The PCR conditions for PKSII (IPF6, IPR6) were $95^{\circ} \mathrm{C}$ for $1 \mathrm{~min}$ for initial denaturation followed by 30 cycles of $94{ }^{\circ} \mathrm{C}$ for $1 \mathrm{~min}$ and $58{ }^{\circ} \mathrm{C}$ for $40 \mathrm{~s}$ and $72{ }^{\circ} \mathrm{C}$ for $2 \mathrm{~min}$ with a final extension of $10 \mathrm{~min}$ at $72{ }^{\circ} \mathrm{C}$. The PCR conditions for NRPS were $95^{\circ} \mathrm{C}$ for $1 \mathrm{~min}$ followed by 35 cycles of $94{ }^{\circ} \mathrm{C}$ for $40 \mathrm{~s}$ and $59{ }^{\circ} \mathrm{C}$ for $1 \mathrm{~min}$ and $72{ }^{\circ} \mathrm{C}$ for $1.5 \mathrm{~min}$ with a final extension of $10 \mathrm{~min}$ at $72{ }^{\circ} \mathrm{C}$. For PKSI (K1F-M6R) the reaction was done at $95^{\circ} \mathrm{C}$ for $1 \mathrm{~min}$ for initial denaturation followed by 30 cycles of $94^{\circ} \mathrm{C}$ for $40 \mathrm{~s}$ and $55^{\circ} \mathrm{C}$ for $1 \mathrm{~min}$ and $72{ }^{\circ} \mathrm{C}$ for $1.5 \mathrm{~min}$ with a final extension of $10 \mathrm{~min}$ at $72{ }^{\circ} \mathrm{C}$. All the PCR were performed in $25 \mu \mathrm{L}$ tubes each containing $12.5 \mu \mathrm{L}$ of $2 \times$ EasyTaq $^{\circledR}$ PCR SuperMix (TransGen Biotech, Beijing, China), $1 \mu \mathrm{L}$ of forwarding primer, $1 \mu \mathrm{L}$ of reverse primer (each primer of $10 \mathrm{pmol}$ ), $1 \mu \mathrm{L}$ of $100 \mathrm{ng} / \mu \mathrm{L}$ DNA, $1 \%(v / v)$ of DMSO, and DNA-free water to a final volume of $25 \mu \mathrm{L}$. Universal primer sets of 27F, 1500R were used for amplifying the 16s rRNA gene [23]. All PCR amplicons were carried out in TaKaRa PCR Thermal Cycler Dice Touch at the key lab in the school of Science Sun Yat-Sen University, Guangzhou, China.

\subsection{Primary Screening of Antimicrobial Activities by Colony Picking Method}

The primary screening for antimicrobial activities was performed by the colony picking method according to Hettiarachchi et al. [20] with slight modification (Figure 2). In brief, the test strains were prepared into $4 \mathrm{~mL}$ of marine broth $(5.0 \mathrm{~g} / \mathrm{L}$ peptone from soya bean, $1.0 \mathrm{~g} / \mathrm{L}$ yeast extract, $0.3 \mathrm{~g} / \mathrm{L}$ dipotassium hydrogen phosphate, $1.0 \mathrm{~g} / \mathrm{L}$ glucose, $5.0 \mathrm{~g} / \mathrm{L}$ sodium chloride), shaking at $120 \mathrm{rpm}$, and incubation at room temperature (approximately $30^{\circ} \mathrm{C}$ due to the in-situ temperature of $28.1-28.3^{\circ} \mathrm{C}$ when collecting samples) for $18-24 \mathrm{~h}$ until the concentration of bacteria was a measure of the $0.5 \mathrm{McFarland}$ standard [24], approximately $10^{8} \mathrm{cfu} / \mathrm{mL}$. Then, the test trains were diluted 200 times in the culture medium to have the test strains of $5 \times 10^{5} \mathrm{cfu} / \mathrm{mL}$. A $100 \mu \mathrm{L}$ culture of $5 \times 10^{5} \mathrm{cfu} / \mathrm{mL}$ for each test strain was spread onto Mueller Hinton agar (MHA, India) plates, and then the SAB strains were picked up from a 3 day cultivation colony on R2A agar medium and introduced to make a lawn on agar plates; one sponge-associated bacterium was applied for one test strain only. The plates were incubated with test strains B. subtilis, S. aureus, S. typhimurium, and E. coli at $37^{\circ} \mathrm{C}$, V. campbellii, V. parahaemolyticus, and S. marcescens at $25^{\circ} \mathrm{C}$, and the yeast $\mathrm{C}$. albicans at $30^{\circ} \mathrm{C}$ for up to 3,5 , or 7 days. 
The appearance of a clear zone surrounding target strains demonstrated the inhibition of SAB against test strains.

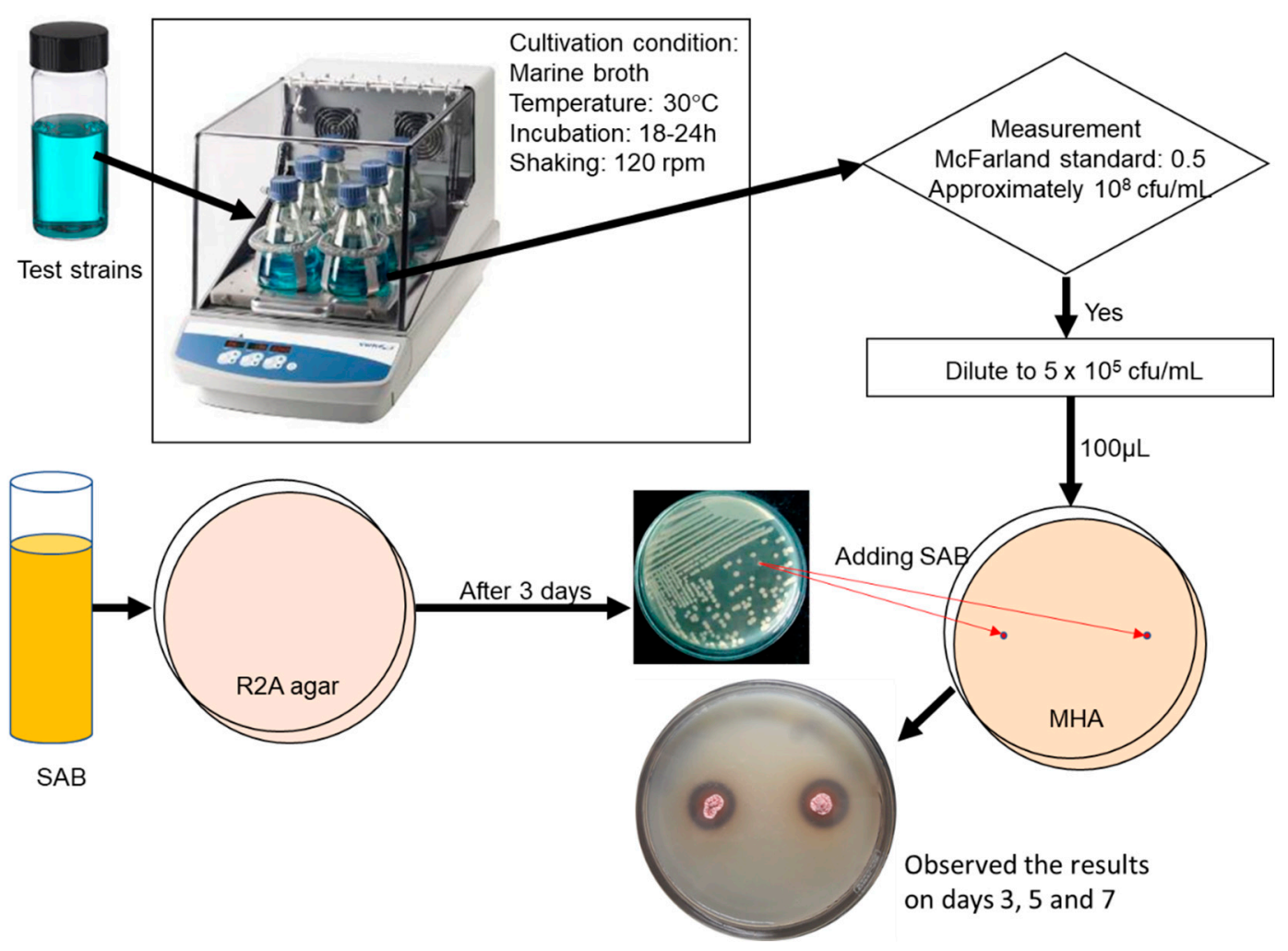

Figure 2. Flows chart of primary screening for antimicrobial activities for one test (SAB: sponge-associated bacteria; MHA: Mueller Hinton agar).

The SAB strains were streaked in marine agar plates for 3-5 days and then inoculated into $300 \mathrm{~mL}$ Erlenmeyer flasks containing $100 \mathrm{~mL}$ BM medium (yeast extract: $1 \mathrm{~g} / \mathrm{L}$, beef extract: $1 \mathrm{~g} / \mathrm{L}$, tryptone: $2 \mathrm{~g} / \mathrm{L}$, glucose: $10 \mathrm{~g} / \mathrm{L}$, and $1000 \mathrm{~mL}$ filtered sea water). After $72 \mathrm{~h}$ of incubation at $30^{\circ} \mathrm{C}$ with shaking at $120 \mathrm{rpm}$, the bacterial cells and the supernatants were homogenized using an ultrasonic processor for $30 \mathrm{~s}$ to break the cells. The homogenized broth was extracted with ethyl acetate $1 / 1(v / v)$. Crude extract was dried and re-suspended in $1 \mathrm{~mL}$ of methanol (Merck). The methanolic extract was applied for an antimicrobial activity test.

\subsection{Antimicrobial Activity Testing by Well Diffusion Method}

The antimicrobial activity was conducted by the well diffusion method [25]. Each $100 \mu \mathrm{L}$ of cultured broth of overnight tested strains was spread on the MHA plates; the wells were punched by $6 \mathrm{~mm}$ diameter with a sterile Corning long disposable glass Pasteur pipette. A $30 \mu \mathrm{L}$ methanolic extract of each SAB was pipetted into four available wells on MHA containing tested bacteria. The same amount of methanol without extract was used as a negative control. A disc of $30 \mu \mathrm{g}$ tetracycline (BioRad France) was used as a positive control. All the plates tested with B. subtilis, S. typhimurium, and $E$. coli were incubated at $37^{\circ} \mathrm{C}$ for $24 \mathrm{~h}$. The plates tested with $S$. marcescens were incubated at $25^{\circ} \mathrm{C}$ for $24 \mathrm{~h}$. The zone of inhibition was measured, and the value was expressed as a mean of measured wells excluding the well diameter (Figure 3). 

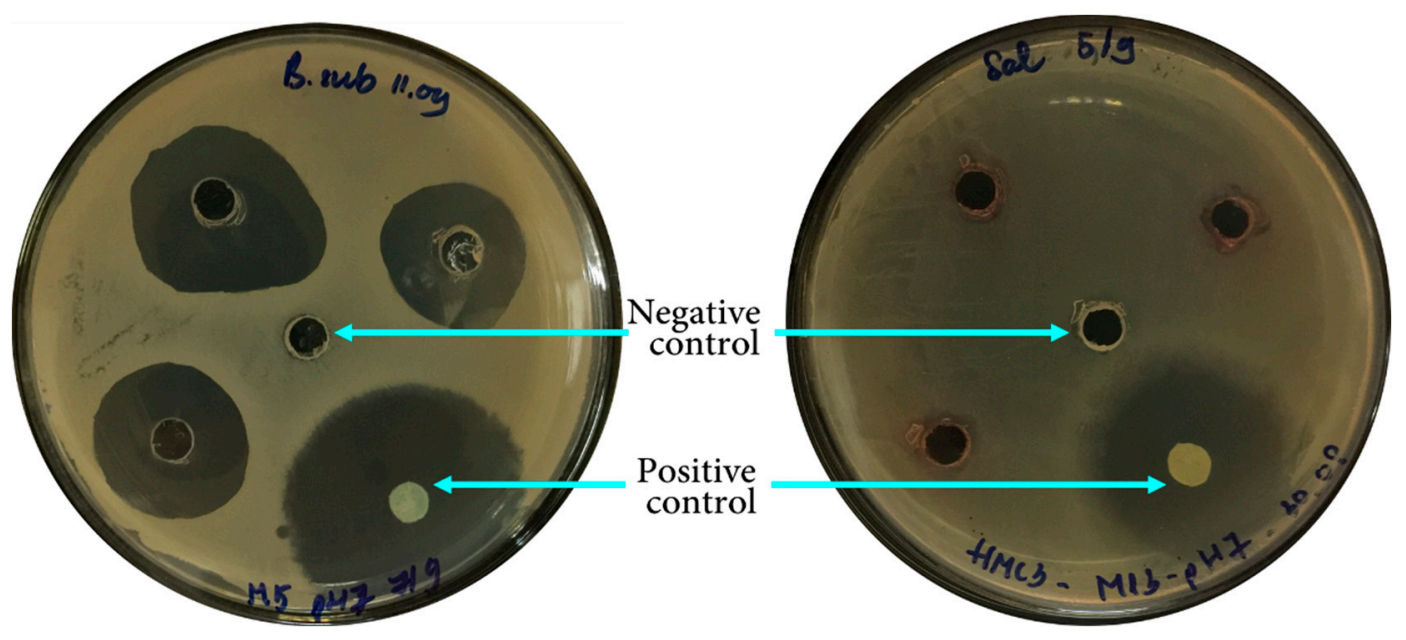

Figure 3. An example of plates tested for sponge-associated bacteria.

\subsection{Identification of Antimicrobial Producing Strains}

Antibacterial producing strains were identified by the traditional method with the addition of $16 \mathrm{~s}$ rRNA gene analysis [26].

\subsection{Data Analysis}

All data were processed using Microsoft Excel 2016. All experiments were repeated three times. The results are stated as the mean \pm standard deviation.

\section{Results}

\subsection{Sponge Associated Bacteria with PKS- and NRPS-Holders}

The results of holder genes strains (Table 1 and Figure 4) showed six out of 25 isolates possessing NRPS and five isolates with PKSII cluster genes. The NRPSs plated from lane 1 to lane 11 in sequences of HM2, HM5, HM6, HM8, HM9, HM12, HM19, HM20, HM21, HM22, and HM23, Ne (negative control for NRPS), M (marker), then next to PKSII from lane 1 to lane 11 with the same order of above strains and ending with $\mathrm{Ne}$ (negative control for PKSII).

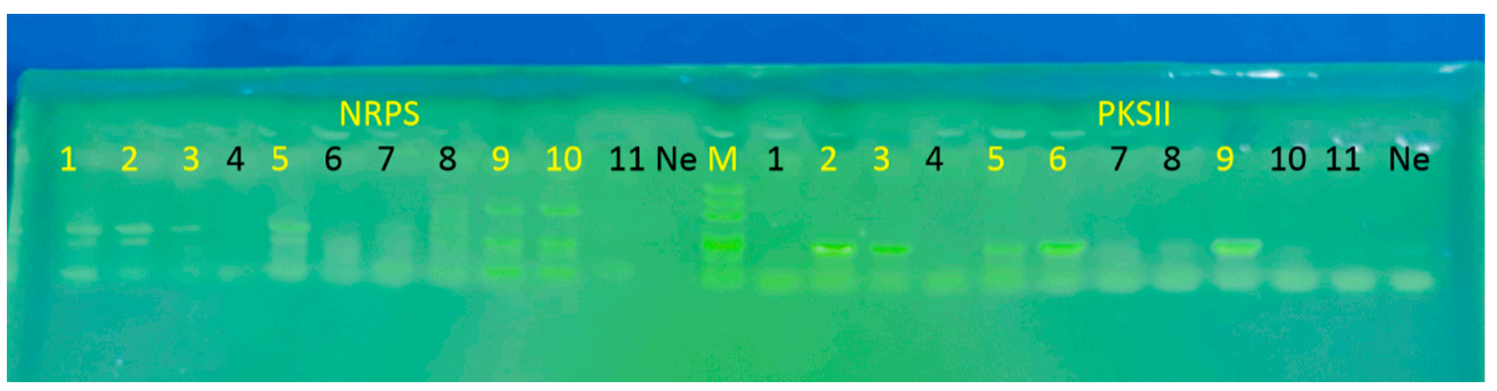

Figure 4. Non-ribosomal peptide synthetases (NRPS) and Polyketide synthases type II (PKSII) holder isolates. Left to right NRPS lane 1 to lane 11 (HM2, HM5, HM6, HM8, HM9, HM12, HM19, HM20, HM21, HM22, and HM23) and Ne (negative control for NRPS); M (marker); and left to right PKSII lane 1 to lane 11 (HM2, HM5, HM6, HM8, HM9, HM12, HM19, HM20, HM21, HM22, and HM23) and Ne (negative control for PKSII). 
Table 1. List of sponge-associated bacteria with basic characteristics (Notation: ND, not detected; CZ, colony size in mm; NRPS, non-ribosomal peptide synthetases; PKSII, polyketide synthases II).

\begin{tabular}{|c|c|c|c|}
\hline Isolates & Colony Color & $\begin{array}{l}\text { Colony Shapes and Sizes after } 48 \mathrm{~h} \text { on } \\
\text { R2A Medium }\end{array}$ & Genes Holder \\
\hline HM1 & Off-white & $\begin{array}{l}\text { Round, concentric circle, convex surface. } \\
\text { CZ 3-4. }\end{array}$ & ND \\
\hline HM2 & Opaque & Round, smooth wet surface. CZ 3-4. & NRPS \\
\hline HM3 & Off-white & Round, convex surface. CZ 3-4. & ND \\
\hline HM4 & Opaque & Circular. Punctiform colonies. & ND \\
\hline HM5 & Off-white & $\begin{array}{l}\text { Round, convex concentric. Rod cell } \\
\text { shape. CZ 1-2. }\end{array}$ & $\begin{array}{l}\text { NRPS } \\
\text { PKSII }\end{array}$ \\
\hline HM6 & Off-white & $\begin{array}{l}\text { Circular, raised smooth surface. Rod } \\
\text { cell shape. CZ 3-5. }\end{array}$ & $\begin{array}{l}\text { NRPS } \\
\text { PKSII }\end{array}$ \\
\hline HM7 & Milky-white & $\begin{array}{l}\text { Dry surface lobes, irregular form. } \\
\text { CZ 3-5. }\end{array}$ & ND \\
\hline HM8 & Milky-white & $\begin{array}{l}\text { Circular, raised, smooth, curled. Rod } \\
\text { cell shape. CZ 5-7. }\end{array}$ & ND \\
\hline HM9 & Reddish & $\begin{array}{l}\text { Round, convex, concentric circle, white } \\
\text { layer like chalk dust. Network long rod } \\
\text { cell. CZ 1-2. }\end{array}$ & $\begin{array}{l}\text { NRPS } \\
\text { PKSII }\end{array}$ \\
\hline HM10 & White & Round, smooth surface. Punctiform. & ND \\
\hline HM11 & Brown & Lobe form, smooth wet surface. CZ 2-3. & ND \\
\hline HM12 & Off-white & $\begin{array}{l}\text { Circular, smooth, raised. Coccus cell. } \\
\text { Punctiform. }\end{array}$ & PKSII \\
\hline HM13 & Milky-white & $\begin{array}{l}\text { Round, convex, wet lobe surface. } \\
\text { CZ 1-2. }\end{array}$ & ND \\
\hline HM14 & Bright & $\begin{array}{l}\text { Round, convex, iridescent surfaces. } \\
\text { CZ 3-4. }\end{array}$ & ND \\
\hline HM15 & Off-white & $\begin{array}{l}\text { Round, jagged edges, pale protruding } \\
\text { center. CZ 3-4. }\end{array}$ & ND \\
\hline HM16 & Off-white & Round colonies, rough surface. CZ 2-3 & ND \\
\hline HM17 & Milky-white & Round, dry edges, lobed border. CZ 4-5 & ND \\
\hline HM18 & Milky-white & Round, smooth. CZ 1-2. & ND \\
\hline HM19 & Brown & $\begin{array}{l}\text { Round, convex iridescent, wet } \\
\text { surface.CZ 1-2. }\end{array}$ & ND \\
\hline HM20 & Yellow & Round, convex surface. CZ 2-3. & ND \\
\hline HM21 & Milky-white & Round, convex, darkest center. CZ 4-5. & $\begin{array}{l}\text { NRPS } \\
\text { PKSII }\end{array}$ \\
\hline HM22 & Milky-white & $\begin{array}{l}\text { Radioactive colonies, scald surface, } \\
\text { lobes. Punctiform. }\end{array}$ & NRPS \\
\hline HM23 & Yellow & Round, flat, glossy surface. CZ 2-4. & ND \\
\hline HM24 & Yellow & $\begin{array}{l}\text { Round, smooth wet convex surface. } \\
\text { Punctiform. }\end{array}$ & ND \\
\hline HM25 & Opaque & $\begin{array}{l}\text { Round form, smooth wet convex } \\
\text { surface. CZ 2-4. }\end{array}$ & ND \\
\hline
\end{tabular}




\subsection{Antimicrobial Tests}

The results of the primary screening of the holder cluster genes of PKS/NRPS strains for antimicrobial producers are exhibited in Table 2 and Figure 5. When four of seven holder bioactive cluster genes strains showed antagonistic activities, other SAB strains did not present any antimicrobial activities to all tested strains by the colony picking method (Table 2).

Table 2. Primary antibiotic producer strains by colony picking method (Notation: $(+)$ inhibition zone observed; (-) no inhibition zone observed).

\begin{tabular}{cccccccc}
\hline \multirow{2}{*}{ Test Strains } & \multicolumn{7}{c}{ Holder PKS/NRPS Strains } \\
\cline { 2 - 7 } & HM2 & HM5 & HM6 & HM9 & HM12 & HM21 & HM22 \\
\hline B. subtilis & - & - & + & + & + & - & - \\
S. aureus & - & - & - & - & - & - & - \\
E. coli & - & - & - & - & - & - & - \\
S. typhimurium & - & - & - & - & - & - & - \\
S. marcescens & - & - & - & - & - & + & - \\
C. albicans & - & - & - & - & - & - & - \\
V. parahaemolyticus & - & - & - & - & - & - & - \\
V. campbellii & - & - & - & - & - & - & - \\
\hline
\end{tabular}
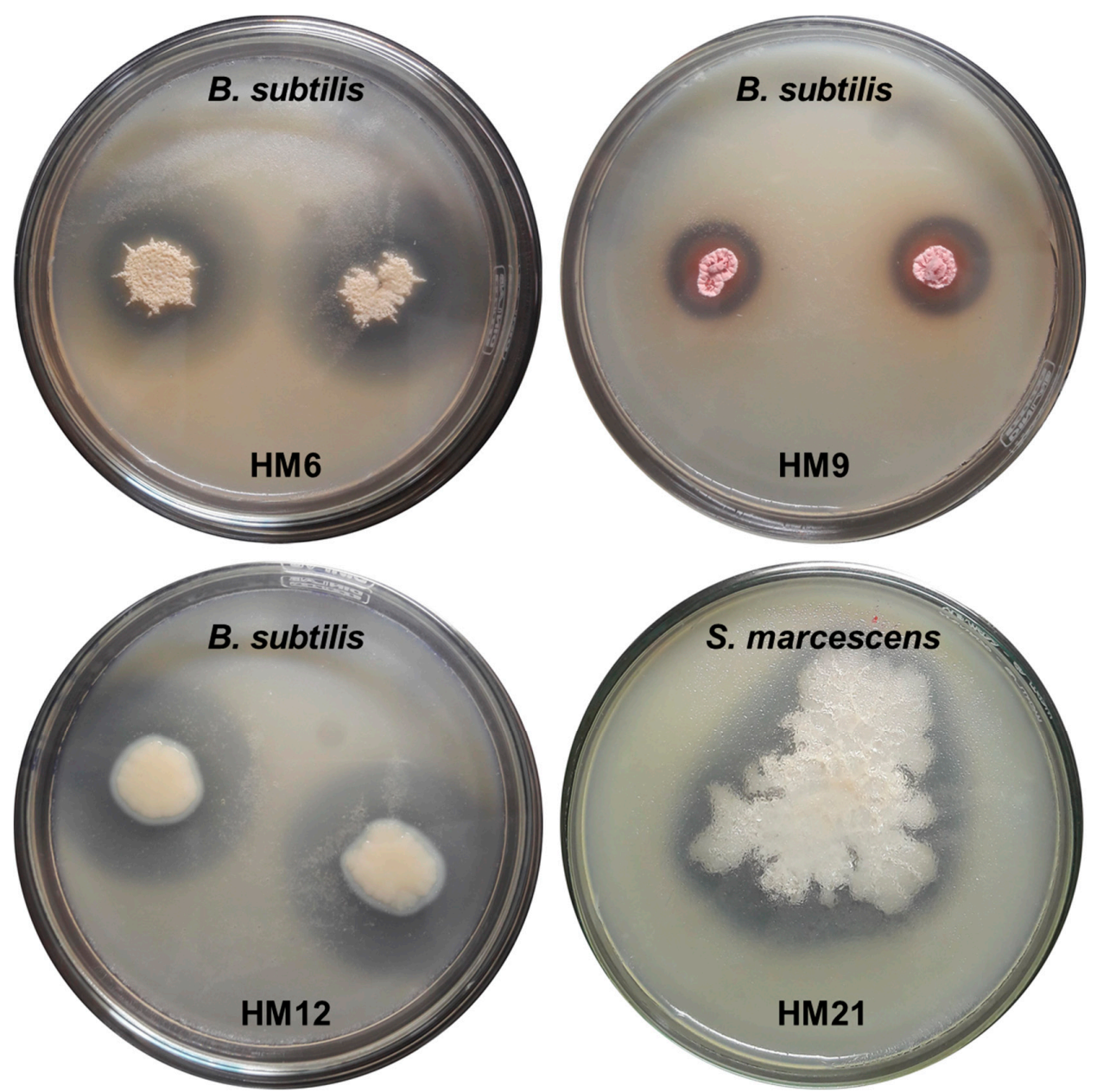

Figure 5. Antagonistic activities of SAB (sponge-associated bacteria) by colony picking method. The pattern was the test strains (such as B. subtilis and S. marcescens) and HM\# was SAB in the center of antibacterial regions. 
Antimicrobial activity of the SAB (Figure 6 and Table 3) indicated that among 25 isolates tested, eleven strains (44\%) exhibited antibacterial activities. The three strains, HM2, HM21, and HM23, showed a pattern of B. subtilis only. Two other strains, HM5 and HM8, possessed patterns of B. subtilis and E. coli, whereas the strain HM12 showed patterns of B. subtilis and S. marcescens. The isolates HM19 possessed patterns of E. coli, S. marcescens, and S. typhimurium. Particularly, the strains HM6 and HM20 were shown to be very potent antimicrobial producers, with patterns of B. subtilis, E. coli, S. marcescens, and S. typhimurium. The strain HM22 showed activity against only coral pathogenic S. marcescens. Interestingly, it exhibited the highest level of inhibition compared to other strains which were inhibiting the growth of this tested bacterium. Genetic screening revealed that the strain HM20 had neither PKS nor NRPS. Additionally, the colony picking method showed that this strain was not active against any tested bacteria. However, the crude extract from this isolate inhibited against four tested strains.

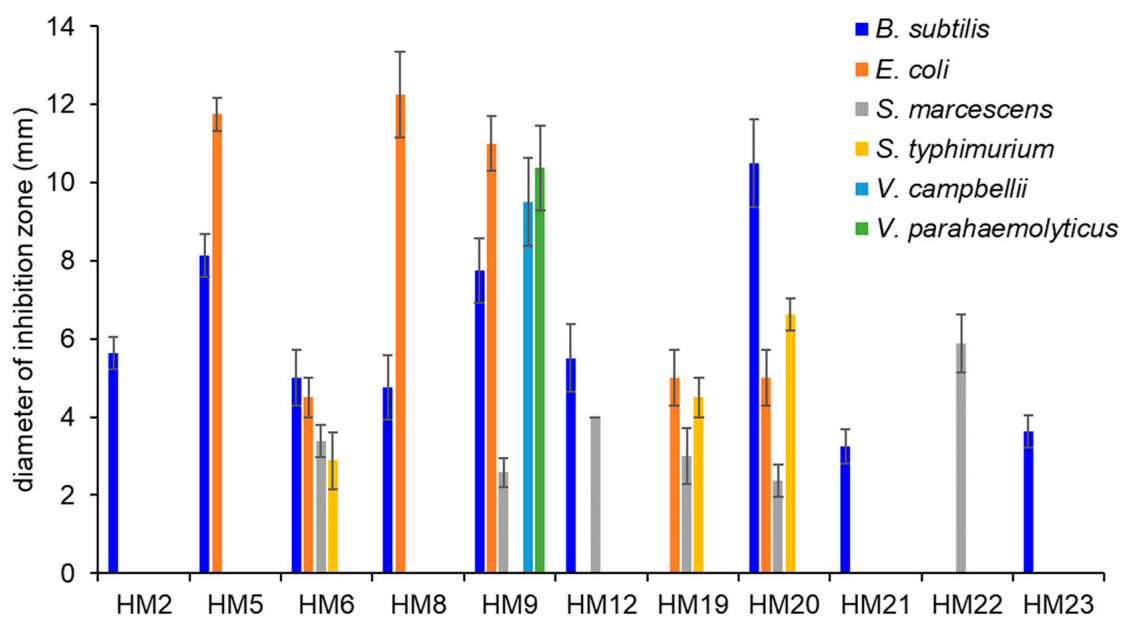

Figure 6. Antimicrobial activities of sponge-associated bacteria.

Table 3. Classification of antibiotic producing strains (Notation: ND, not detected; NRPS, non-ribosomal peptide synthetases; PKSII, polyketide synthases II; the letters A, B, C, D, E, and F denote types of antimicrobial patterns against Bacillus subtilis, Escherichia coli, Serratia marcescens, Salmonella typhimurium, Vibrio campbellii, and Vibrio parahaemolyticus, respectively).

\begin{tabular}{|c|c|c|c|c|c|}
\hline $\begin{array}{l}\text { Isolate } \\
\text { Code }\end{array}$ & NRPS/PKS & $\begin{array}{l}\text { Colony } \\
\text { Picking }\end{array}$ & Well Diffusion & Next Related Type Strains (RDPII) & Possible Genus \\
\hline HM2 & NRPS & ND & A & $\begin{array}{l}\text { Bacillus amyloliquefaciens }{ }^{\mathrm{T}} \text { FZB42 } \\
\text { (CP000560: } 99.6 \%)\end{array}$ & Bacillus sp. \\
\hline HM5 & $\begin{array}{l}\text { NRPS } \\
\text { PKSII }\end{array}$ & ND & A, B & $\begin{array}{l}\text { Bacillus amyloliquefaciens }{ }^{\mathrm{T}} \text { FZB42 } \\
\text { (CP000560: } 98.1 \%)\end{array}$ & Bacillus sp. \\
\hline HM6 & $\begin{array}{l}\text { NRPS } \\
\text { PKSII }\end{array}$ & A & A, B, C, D & $\begin{array}{l}\text { Bacillus amyloliquefaciens }{ }^{\mathrm{T}} \text { FZB42 } \\
\text { (CP000560: } 99.6 \%)\end{array}$ & Bacillus sp. \\
\hline HM8 & ND & ND & A, B & $\begin{array}{l}\text { Bacillus subtilis }{ }^{\mathrm{T}} \text { DSM22148 } \\
\text { (HE582781: } 99.0 \% \text { ) }\end{array}$ & Bacillus sp. \\
\hline HM9 & $\begin{array}{l}\text { NRPS } \\
\text { PKSII }\end{array}$ & A & A, B, C, E, F & $\begin{array}{l}\text { Streptomyces mexicanus }{ }^{\mathrm{T}} \text { NBRC } 100915 \\
\text { (AB249966: } 94 \% \text { ) }\end{array}$ & Streptomyces sp. \\
\hline HM12 & PKSII & A & $\mathrm{A}, \mathrm{C}$ & $\begin{array}{l}\text { Bacillus subtilis }{ }^{\mathrm{T}} \text { DSM } 22148 \\
\text { (HE582781: } 99.5 \% \text { ) }\end{array}$ & Bacillus sp. \\
\hline HM19 & ND & ND & B, C, D & $\begin{array}{l}\text { Bacillus toyonensis }{ }^{\mathrm{T}} \text { CNCM I-1012 } \\
\text { (AJ310100: } 99.8 \%)\end{array}$ & Bacillus sp. \\
\hline HM20 & ND & ND & A, B, C, D & $\begin{array}{l}\text { Bacillus safensis }{ }^{\mathrm{T}} \mathrm{FO}-036 \mathrm{~b} \\
\text { (AF234854: } 99.6 \%)\end{array}$ & Bacillus sp. \\
\hline HM21 & $\begin{array}{l}\text { NRPS } \\
\text { PKSII }\end{array}$ & $\mathrm{C}$ & A & $\begin{array}{l}\text { Bacillus amyloliquefaciens }{ }^{\mathrm{T}} \text { FZB42 } \\
\text { (CP000560: } 99.6 \%)\end{array}$ & Bacillus sp. \\
\hline HM22 & NRPS & ND & $\mathrm{C}$ & $\begin{array}{l}\text { Bacillus safensis }{ }^{\mathrm{T}} \mathrm{FO}-036 \mathrm{~b} \\
(\mathrm{AF} 234854: 100 \%)\end{array}$ & Bacillus sp. \\
\hline HM23 & ND & ND & $\mathrm{A}$ & $\begin{array}{l}\text { Bacillus cereus }{ }^{\mathrm{T}} \text { ATCC } 14579 \\
(\text { AE016877: } 99.6 \%)\end{array}$ & Bacillus sp. \\
\hline
\end{tabular}




\subsection{Identification of Potential Strains.}

Results of analysis of 16s RNA genes of active strains (Table 3) showed that most strains were identified as Bacillus sp., except strain HM9, which was Streptomyces sp. The strain HM9 was the nearest to the type strain Streptomyces mexicanus ${ }^{\mathrm{T}}$ NBRC100915 (AB249966: 94\%). This actinomyces was thought to be a well-known source of antibiotics so far, for instance, gougerotin, a water-soluble antibiotic with non-antifungal activity [27].

Additionally, members of Bacillus species showed effective inhibitory activity to all four test microorganisms, and they were reported as potential strains for biologically active substance producers. In addition, pure substances obtained from Bacillus sp. were capable of inhibiting some cancer cells and some important enzymes [28]. Most recently, Bacillus sp. strain BC028 isolated from the blue mussel Mytilus edulis also was reported as a new hexapeptide producer; this strain produced a natural biological active compound considered as a new antibiotic, and it showed inhibition of the growth of opportunistic pathogenic Enterococcus faecalis and pathogenic $S$. aureus with rather low minimum inhibition concentration values of 8 and $12 \mu \mathrm{M}$, respectively [29].

Although the strains HM8, HM19, HM20, and HM23 showed antimicrobial activity in well diffusion with broth culture extract, they did not show antimicrobial activities in the colony picking method, and all three types of potent bioactive coding genes were not found (Table 3).

The bioactive coding genes were found in some strains including HM6, HM9, and HM12, and these strains also showed antimicrobial ability in both the colony picking method and well diffusion of crude extracts. The result of the presence of PKS genes in HM21 and HM22 strains are somewhat uncertain (Figure 2), but the strain HM21 showed inhibition against $S$. marcescens with the colony picking method, and its crude extract inhibited against $B$. subtilis, while the strain HM22 did not have any inhibition activity against indicator strains but crude extract of this strain inhibited the coral pathogen S. marcescens.

\section{Discussion}

Research on microorganisms from sponges in Son Cha revealed the number of microorganisms isolated from six different species of sponges ranging from $150-820 \mathrm{cfu} / \mathrm{g}$. However, the microorganisms in that study were isolated from samples stored at $-20{ }^{\circ} \mathrm{C}$ [30]. The fresh hard coral-associated bacteria reported $1.32 \pm 0.98 \times 10^{6} \mathrm{cfu} / \mathrm{g}$ wet sample by the culture based method, whereas the total number of heterotrophic bacteria counted directly from the fluorescence dye method was $2.07 \pm 0.58 \times 10^{8}$ cells/g [31]. In addition, bacteria also were isolated from marine sediment, and the heterotrophic bacteria were recorded at $1.5 \times 10^{6} \mathrm{cfu} / \mathrm{g}$ sediment in the waters of Mot Island [32]. Microorganisms that live with the hosts, such as sponges, urchins, corals, mollusks, or other invertebrates were reported to have very high specificity and strongly depended on their hosts. Moreover, they also have inherent characteristics of microorganisms such as nutrient requirements, culture conditions, and so on, and of course, initial host states had crucial effectiveness for the isolation of microorganisms. Those important impact factors have a huge influence on the number of isolated microorganisms and types of isolates as well. From the large number of microorganisms counted on the various dilution levels mentioned above, this study isolated 25 pure strains with distinct shapes, color characteristics, and different cell sizes. The community of microbials associated with the Chondrilla nucular in the Mediterranean Sea was very diverse, as expressed by shape and size under scanning electron microscopy and by analysis of the 16s rRNA gene and the visual genes with 22 different phylotypes of associated bacteria [33]. Microorganisms consisted of 40 to $60 \%$ of the total biomass of their hosts and reached more than $10^{9} \mathrm{cells} / \mathrm{cm}^{3}$, which was three to four times higher than those of marine bacteria with $10^{6} \mathrm{~mL} / \mathrm{L}$ [34]. Imhoff et al. [10] reported that actinobacteria groups and Firmicutes were found to be a source of holders of those bioactive coding genes, and in particular, the PKSII clusters were more successfully detected than the others.

Using degenerate primers MDPQQRf and HGTGTr for all the heterotrophic bacteria (non-actinomyces), amplification of the PKSI genes was efficiently done, and PKSI were detected 
with abundant bacterial strains such as Ruegeria arenilitoris, Pseudomonas aeruginosa, Bacillus aquimaris, Marinobacter vinifirmus, and Pseudovibrio sp. Similar to the detection of PKSI for non-actinomyces strains, primers MTf and MTr were used to amplify NRPS, and thus the study found antimicrobial activity strains such as Pseudomonas azotoformans, and Ruegeria arenilitoris strain G-M8. The well-known set primers of A3F and A7R were used to amplify NRPS in actinomyces successfully, with Kocuria rhizophilia strain TA68 possessing NRPS and showing activity against K. pneumoniae, E. coli, and Candida albicans. Other actinomyces, the Sanguibacter inulinus strain ST50, showed inhibition of the fungi A. niger (ATCC 16888) and the human pathogenic yeast C. albicans (ATCC 10231). Actually, the set of primers K1, M6R and A3F, A7R targeting for PKSI and NRPS, respectively, used in this study have been successfully applied for actinomyces rather than heterotrophic bacteria. That may be a reason why non-PKSI were detected in this present study when using primers K1, M6R. Other actinomycetes isolated from the sponge Kytococcus sedentarius strain DSM 20547, K. pneumoniae (ATCC BAA-1705), A. niger (ATCC 16888), or Bacillus safensis strain NBRC 100,820 possessed antimicrobial activity that inhibited E. coli, while none of both bioactive genes were detected.

Previously, a cross streak method was used for antimicrobial producer screening; all the associated bacteria isolated from the hard coral Acropora muricata exhibited non-antibiotic producers [13]. However, other papers reported that the cross-streak method was a suitable method for screening of the actinomyces group. A total of 21 actinomycetes isolated from marine environments were tested for antimicrobial activities against eight pathogenic bacteria, and the results revealed that all tested strains showed inhibition of at least one of eight tested bacteria [35]. The actinomycetes isolated from the soil also showed as a good source of antibiotic producers after screening by the cross streak method [36,37]. Hettiarachchi et al. [20] introduced the colony picking method for screening of antibiotic producers; that method seemed to be fast, easy, and efficient for other groups of bacteria, such as Pseudoalteromonas, rather than actinomyces

Recently, our other study reported that associated bacteria with coral species in central Vietnam fluctuated by following time [31,38]. In particular, the strain Bacillus sp. was the most common found among isolates from the coral Acropora hyacinthus and inhibition against coral pathogenic bacterium S. marcescens strain PDL100 but no inhibition of other indicators such as B. subtilis, S. typhimurium, and E. coli 0157 by the agar well diffusion method [31]. So far, Nguyen et al. [39] reported that 7 out of 11 bacteria isolated from the hard corals were active strains and inhibited the growth of B. subtilis, S. typhimurium, and E. coli, whereas the other four strains inhibited activity against S. typhimurium. Noteworthily, the strain S. marcescens, known to cause a severe disease named "white spot" on reef-building coral A. palmata in the Florida Keys, United States, was used as a test strain [40].

This presented study reported that bacterial isolates showed antimicrobial activity, but both cluster genes were not detected. On the other hand, some bacteria strains possessed PKS/NRPS and no inhibition of all tested microorganisms. We suggested screening of secondary metabolites from microbials by firstly using a molecular approach besides traditional methods that may be efficient for choosing marine strains for natural compound discovery. In fact, PKS and NRPS were thought to be easily found in active strains. However, this results depended mostly on the primers. The efficient primers were tested for actinomyces in contrast to the poor investigation of primers for marine heterotrophic bacteria. The sponge-associated bacteria were screened for bioactive compound producers with well-known primers for actinomyces. This approach will be more convincing when more specific primers for marine bacteria are used.

Author Contributions: Conceptualization, P.T.M.; Formal analysis, P.T.M., B.C., L.L. and P.M.-T.; Funding acquisition, P.T.M. and H.X.B.; Investigation, P.T.M. and H.X.B.; Methodology, P.T.M., B.C., L.L. and P.M.-T.; Project administration, D.V.H.; Resources, P.T.M. and H.X.B.; Supervision, D.V.H.; Writing-review and editing, P.T.M., D.V.H. and P.M.-T. All authors have read and agreed to the published version of the manuscript.

Funding: This research was funded by Vietnam National Foundation for Science and Technology Development (NAFOSTED), grant number 106-NN.06-2015.83. 
Acknowledgments: We thank VAST project (grant number VAST02.01/17-18) and national project (grant number ĐTĐL.CN-28/17) for their sharing of data, the VAST Key Lab for Food and Environment Safety in Central Vietnam, Institute of Oceanography-VAST for providing facilities to conduct experiments, and Mr. Thai Minh Quang for his picture of coral.

Conflicts of Interest: The authors declare no conflict of interest.

\section{References}

1. Love, G.D.; Grosjean, E.; Stalvies, C.; Fike, D.A.; Grotzinger, J.P.; Bradley, A.S.; Kelly, A.E.; Bhatia, M.; Meredith, W.; Snape, C.E.; et al. Fossil steroids record the appearance of Demospongiae during the Cryogenian period. Nature 2009, 457, 718-721. [CrossRef]

2. Blunt, J.W.; Copp, B.R.; Hu, W.P.; Munro, M.H.; Northcote, P.T.; Prinsep, M.R. Marine natural products. Nat. Prod. Rep. 2009, 26, 170-244. [CrossRef]

3. Wang, H.; Fewer, D.P.; Holm, L.; Rouhiainen, L.; Sivonen, K. Atlas of nonribosomal peptide and polyketide biosynthetic pathways reveals common occurrence of nonmodular enzymes. Proc. Natl. Acad. Sci. USA 2014, 111, 9259-9264. [CrossRef]

4. Aleti, G.; Sessitsch, A.; Brader, G. Genome mining: Prediction of lipopeptides and polyketides from Bacillus and related Firmicutes. Comput. Struct. Biotechnol. J. 2015, 13, 192-203. [CrossRef]

5. Zhao, X.; Kuipers, O.P. Identification and classification of known and putative antimicrobial compounds produced by a wide variety of Bacillales species. BMC Genom. 2016, 17, 882. [CrossRef]

6. Bérdy, J. Thoughts and facts about antibiotics: Where we are now and where we are heading. J. Antibiot. 2012, 65, 385. [CrossRef]

7. Gu, J.; Codd, R. Copper(II)-based metal affinity chromatography for the isolation of the anticancer agent bleomycin from Streptomyces verticillus culture. J. Inorg. Biochem. 2012, 115, 198-203. [CrossRef] [PubMed]

8. Khan, S.T.; Komaki, H.; Motohashi, K.; Kozone, I.; Mukai, A.; Takagi, M.; Shin-ya, K. Streptomyces associated with a marine sponge Haliclona sp.; biosynthetic genes for secondary metabolites and products. Environ. Microbiol. 2011, 13, 391-403. [CrossRef] [PubMed]

9. Xin, Y.; Kanagasabhapathy, M.; Janussen, D.; Xue, S.; Zhang, W. Phylogenetic diversity of Gram-positive bacteria cultured from Antarctic deep-sea sponges. Polar Biol. 2011, 34, 1501-1512. [CrossRef]

10. Imhoff, J.F.; Labes, A.; Wiese, J. Bio-mining the microbial treasures of the ocean: New natural products. Biotechnol. Adv. 2011, 29, 468-482. [CrossRef]

11. Leal, M.C.; Sheridan, C.; Osinga, R.; Dionisio, G.; Rocha, R.J.; Silva, B.; Rosa, R.; Calado, R. Marine microorganism-invertebrate assemblages: Perspectives to solve the "supply problem" in the initial steps of drug discovery. Mar. Drugs 2014, 12, 3929-3952. [CrossRef] [PubMed]

12. Indraningrat, A.A.; Smidt, H.; Sipkema, D. Bioprospecting Sponge-Associated Microbes for Antimicrobial Compounds. Mar. Drugs 2016, 14, 87. [CrossRef] [PubMed]

13. Fuerst, J.A. Diversity and biotechnological potential of microorganisms associated with marine sponges. Appl. Microbiol. Biotechnol. 2014, 98, 7331-7347. [CrossRef] [PubMed]

14. Imhoff, J.F. Natural Products from Marine Fungi-Still an Underrepresented Resource. Mar. Drugs 2016, 14, 19. [CrossRef]

15. Do, T.T.; Duong, T.D.; Nguyen, X.N.; Bui, H.T.; Pham, H.Y.; Hoang, L.T.A.; Do, C.T.; Chau, V.M.; Phan, V.K. Furanosesterterpenes from the marine sponge Ircinia echinata (Keller, 1889). Vietnam J. Chem. 2016, 54, 477. [CrossRef]

16. Nguyen, H.T.; Chau, V.M.; Tran, T.H.; Phan, V.K.; Hoang, T.H.; Nguyen, T.D.; Nguyen, X.N.; Tai, B.H.; Hyun, J.H.; Kang, H.K.; et al. C29 sterols with a cyclopropane ring at C-25 and 26 from the Vietnamese marine sponge Ianthella sp. and their anticancer properties. Bioorg. Med. Chem. Lett. 2009, 19, 4584-4588. [CrossRef]

17. Trinh, T.T.V.; Truong, B.N.; Longeon, A.; Doan, T.M.H.; Deville, A.; Chau, V.M.; Pham, V.C.; Bourguet-Kondracki, M.L. New 9alpha-Hydroxy-5alpha,6alpha-epoxyhydroxysterols from the Vietnamese Marine Sponge Ircinia echinata. Mar. Drugs 2018, 16, 424. [CrossRef]

18. Ton, T.H.D.; Steinert, G.; Nguyen, T.K.C.; Smidt, H.; Sipkema, D. Archaeal and bacterial diversity and community composition from 18 phylogenetically divergent sponge species in Vietnam. PeerJ 2018, 6, e4970. [CrossRef] 
19. Lim, S.-C.; Putchakarn, S.; Thai, M.-Q.; Wang, D.; Huang, Y.M. Inventory of sponge fauna from the Singapore Strait to Taiwan Strait along the western coastline of the South China Sea. Raffles Bull. Zool. 2016, 34, $104-129$.

20. Hettiarachchi, S.; Lee, S.J.; Lee, Y.; Kwon, Y.K.; De Zoysa, M.; Moon, S.; Jo, E.; Kim, T.; Kang, D.H.; Heo, S.J.; et al. A Rapid and Efficient Screening Method for Antibacterial Compound-Producing Bacteria. J. Microbiol. Biotechnol. 2017, 27, 1441-1448. [CrossRef]

21. Ayuso-Sacido, A.; Genilloud, O. New PCR Primers for the Screening of NRPS and PKS-I Systems in Actinomycetes: Detection and Distribution of These Biosynthetic Gene Sequences in Major Taxonomic Groups. Microb. Ecol. 2005, 49, 10-24. [CrossRef] [PubMed]

22. Metsä-Ketelä, M.; Salo, V.; Halo, L.; Hautala, A.; Hakala, J.; Mäntsälä, P.; Ylihonko, K. An efficient approach for screening minimal PKS genes from Streptomyces. FEMS Microbiol. Lett. 1999, 180, 1-6. [CrossRef]

23. Woese, C.R.; Gutell, R.; Gupta, R.; Noller, H.F. Detailed analysis of the higher-order structure of 16S-like ribosomal ribonucleic acids. Microbiol. Rev. 1983, 47, 621-669. [CrossRef] [PubMed]

24. Wikler, M.A.; Hindler, J.F.; Cockerill, F.R.; Patel, J.B.; Bush, K.; Powell, M.; Dudley, M.N.; Turnidge, J.D.; Eliopoulos, G.M.; Weinstein, M.P.; et al. Methods for Dilution Antimicrobial Susceptibility Tests for Bacteria that Grow Aerobically, Approved Standard-Eighth Edition; Clinical and Laboratory Standards Institute: Wayne, PA, USA, 2009; Volume 29.

25. Bauer, A.W.; Kirby, W.M.; Sherris, J.C.; Turck, M. Antibiotic susceptibility testing by a standardized single disk method. Am. J. Clin. Pathog. 1966, 45, 493-496. [CrossRef]

26. Pham, T.M.; Wiese, J.; Wenzel-Storjohann, A.; Imhoff, J.F. Diversity and antimicrobial potential of bacterial isolates associated with the soft coral Alcyonium digitatum from the Baltic Sea. Anton. Leeuw. 2016, 109, 105-119. [CrossRef] [PubMed]

27. Wei, J.; Tian, Y.; Niu, G.; Tan, H. GouR, a TetR family transcriptional regulator, coordinates the biosynthesis and export of gougerotin in Streptomyces graminearus. Appl. Environ. Microbiol. 2014, 80, 714-722. [CrossRef] [PubMed]

28. Pham, T.M. Community of Soft Coral Alcyonium Digitatum Associated Bacteria and Their Antimicrobial Activities. Ph.D. Thesis, Christian-Albrecht University of Kiel, GEOMAR, Kiel, Germany, 2014.

29. Wiese, J.; Abdelmohsen, U.R.; Motiei, A.; Humeida, U.H.; Imhoff, J.F. Bacicyclin, a new antibacterial cyclic hexapeptide from Bacillus sp. strain BC028 isolated from Mytilus edulis. Bioorg. Med. Chem. Lett. 2018, 28, 558-561. [CrossRef]

30. Pham, V.C.; Nguyen, M.A.; Vu, T.Q.; Nguyen, T.K.C. Isolation, screening and identification of some sponge associated bacterial isolates from six marine sponge species of Son Cha coast. Vietnam J. Biol. 2015, 36, 345-350.

31. Pham, T.M.; Nguyen, N.T.; Nguyen, K.H. Bacillus sp. VK2 isolated from Acropora hyacinthus from Ninh Thuan and its antimicrobial activities against cause of white pox disease in Acropora palmate. Vietnam J. Mar. Sci. Technol. 2018, 18, 197-204.

32. Pham, T.M.; Dao, V.H.; Nguyen, K.H. Antibiotic resistance of marine bacteria from Mot Island Nha Trang Bay. Vietnam J. Mar. Sci. Technol. 2017, 17, 466-475.

33. Thiel, V.; Leininger, S.; Schmaljohann, R.; Brümmer, F.; Imhoff, J.F. Sponge-specific Bacterial Associations of the Mediterranean Sponge Chondrilla nucula (Demospongiae, Tetractinomorpha). Microb. Ecol. 2007, 54, 101-111. [CrossRef] [PubMed]

34. Taylor, M.W.; Radax, R.; Steger, D.; Wagner, M. Sponge-Associated Microorganisms: Evolution, Ecology, and Biotechnological Potential. Microbiol. Mol. Biol. Rev. 2007, 71, 295-347. [CrossRef] [PubMed]

35. Valli, S.; Suvathi, S.S.; Aysha, O.S.; Nirmala, P.; Vinoth, K.P.; Reena, A. Antimicrobial potential of Actinomycetes species isolated from marine environment. Asian Pac. J. Trop. Biomed. 2012, 2, 469-473. [CrossRef]

36. Arifuzzaman, M.; Khatun, M.R.; Rahman, H. Isolation and screening of actinomycetes from Sundarbans soil for antibacterial activity. Afr. J. Biotechnol. 2010, 9, 4615-4619.

37. Ceylan, O.; Okmen, G.; Ugur, A. Isolation of soil Streptomyces as source antibiotics active against antibiotic-resistant bacteria. Eurasian J. Biosci. 2008, 2, 73-82.

38. Pham, T.M.; Nguyen, K.H.; Nguyen, M.H.; Phan, M.T.; Hoang, T.D.; Vo, H.T.; Nguyen, T.D.H.; Le, T.D.; Nguyen, H.H. A study on bacteria associated with three hard coral species from Ninh Thuan by epifluorescence and most diluted culture method. J. Mar. Sci. Technol. 2019, 19, 271-283. 
39. Nguyen, K.H.; Pham, T.M.; Bui, H.H.; Vo, H.T. Screening of coral associated bacteria with antimicrobial activities from scleractinian coral Acropora muricata in the Nha Trang bay. Collect. Mar. Work 2016, 22, 83-95.

40. Patterson, K.L.; Porter, J.W.; Ritchie, K.B.; Polson, S.W.; Mueller, E.; Peters, E.C.; Santavy, D.L.; Smith, G.W. The Etiology of White Pox, A Lethal Disease of the Caribbean Elkhorn Coral, Acropora palmata. Proc. Natl. Acad. Sci. USA 2002, 99, 8725-8730. [CrossRef]

(C) 2020 by the authors. Licensee MDPI, Basel, Switzerland. This article is an open access article distributed under the terms and conditions of the Creative Commons Attribution (CC BY) license (http://creativecommons.org/licenses/by/4.0/). 